\section{Evidence for the Incorporation of Lead into Barite from Waste Rock Pile Materials}

\author{
ALEXANDRA COURTIN-NOMADE, ${ }^{*},+$ \\ MARILYNE SOUBRAND-COLIN, ${ }^{+}$ \\ MATTHEW A. MARCUS, ${ }^{\ddagger}$ AND \\ S I R I N E C F A KR A \\ University of Limoges, Laboratoire HydrASA, équipe ETM, \\ UMR 6532 CNRS, FST, 123 avenue Albert Thomas, \\ 87060 Limoges cedex, France and Advanced Light Source, \\ Lawrence Berkeley National Lab, 1 Cyclotron Rd, Berkeley, \\ California 94720
}

Received November 9, 2007. Revised manuscript received January 21, 2008. Accepted January 31, 2008.

Because $\mathrm{Pb}$ is one of the most toxic elements and is found as a major contaminant in mining environments, this study aims to identify the distribution of this element in host phases issued from the alteration of mine wastes. The sampling location was a former mine near Oakland, California (USA). This mine was once a source of sulfide minerals from which sulfuric acid was made. The material discussed in this paper was collected in iron hardpans that were formed within the waste rock pile resulting from the excavation work. In most contaminated environments (soils, mine waste), secondary metal-bearing phases arising from alteration processes are usually fine-grained (from $10 \mu \mathrm{m}$ to less than $1 \mu \mathrm{m}$ ) and highly heterogeneous, requiring the use of micron-scale techniques. We performed microRaman spectroscopy, microscanning X-ray diffraction (SXRD), and microextended X-ray near edge spectroscopy (XANES) to determine the relationships between $\mathrm{Pb}$ and a Ba/Fe-rich host phase. Micro-Raman spectroscopy suggests that $\mathrm{Pb}$ is preferentially incorporated into barite rather than goethite. Results from micro-Raman experiments show the high sensitivity of this analytical tool to the incorporation of $\mathrm{Pb}$ into barite by being especially sensitive to the variations of the $S-0$ bond and showing the characteristic bands due to the contribution of $\mathrm{Pb}$. This association is confirmed and is well-illustrated by microSXRD mineral species maps showing the correlation between $\mathrm{Pb}$ and barite. Microfocused XANES indicates that $\mathrm{Pb}$ is present as $\mathrm{Pb}^{2+}$, agreeing with the in situ physicochemical parameters.

\section{Introduction}

One of the difficulties in studying the distribution of trace elements released from soils, sediments, and ores during weathering processes under various geochemical conditions lies in the intrinsic heterogeneity of environmental solid samples. This necessitates the use of chemically sensitive techniques with micron to submicron resolution (1-4). Furthermore, the alteration products derived from metalbearing phases are usually of small size, frequently are poorly-

* Corresponding author phone: +33 (0) 5554572 92; fax: +33 (0) 5554574 13; e-mail: alexandra.courtin@unilim.fr.

${ }^{\dagger}$ University of Limoges.

${ }^{\ddagger}$ Lawrence Berkeley National Lab. or noncrystalline, and may correspond to complex minerals, intimate intergrowths, or with fine scale heterogeneity, making them difficult to identify by more conventional analytical techniques (5-7).

The bioavailability of metals or metalloids is strongly correlated to their redox state and chemical form (e.g. refs 8 and 9). Their study is of particular interest because their bioavailability and potential migration can pose a risk to human health and the environment, particularly for $\mathrm{Pb}$ as found, for example, in the Coeur d'Alène district (Idaho, USA) (10). The primary source of $\mathrm{Pb}$ is galena $(\mathrm{PbS})$, which, after oxidation, may lead to the precipitation of various secondary phases such as carbonates (e.g., cerussite $\mathrm{PbCO}$ ), sulfates (e.g., anglesite $\mathrm{PbSO}_{4}$ ), or phosphates (e.g., pyromorphite $\left.\mathrm{Pb}_{5} \mathrm{Cl}(\mathrm{PO} 4)_{3}\right)(11-15)$. Iron or Mn oxides have also been reported as potential carriers of $\mathrm{Pb}(16-18)$.

In this investigation, samples consist of iron hardpans developed within waste rock pile originated from a former mining site located in a heavily urbanized area in Oakland, California (USA). Results on the mineralogical distribution (host phases) and speciation of $\mathrm{Pb}$ in a sulfide ore body that was mined for sulfuric acid are presented. This study aims also to evaluate the stability of the different $\mathrm{Pb}$-bearing phases with the evolution of the sulfide ore body alteration. Furthermore, the watershed where the waste rock pile is located consists of waters affected by acid mine drainage and nonaffected streams. The former mine discharges water from a buried adit to a small creek down the waste rock pile and shows acidic $\mathrm{pH}(\sim 3), \mathrm{Eh} \sim 500 \mathrm{mV}$, and various potentially toxic elements such as $\mathrm{Cu}(47 \mu \mathrm{M})$ and $\mathrm{Zn}(138$ $\mu \mathrm{M}$ ) in high concentrations (19). Then, this small creek merges with other, nonaffected, streams and, mainly due to dilution, the $\mathrm{pH}$ is neutralized and the chronic toxicity measured at the mine adit decreases downstream of the watershed (19).

\section{Materials and Methods}

Samples were collected in a former mining site with a highly heterogeneous waste rock pile in which sulfides that have not been processed are now exposed to weathering and where iron-rich hardpans have emerged. The studied phases were observed in these hardpans. The mine exploited an ore body sulfide confined to a keratophyre complex that is an intermediate and silicic volcanic and hypabyssal rock often associated with basalts (20). According to Clark (21), this keratophyre complex is located above a carbonaceous shale deposit, likely belonging to the Knoxville formation.

Thin $(30 \mu \mathrm{m})$ sections made of epoxy-embedded material were used for all analytical analyses. A room-temperaturecuring epoxy was chosen to avoid resin-induced changes in speciation. A standard of $\mathrm{Pb}$ sorbed onto barite was prepared by adding $3 \mathrm{wt} \% \mathrm{~Pb}\left(\mathrm{NO}_{3}\right)_{2}$ to an ultrapure formula synthetic barite $\mathrm{BaSO}_{4}$ with a $24 \mathrm{~h}$ contact time, based on the protocol proposed by Davranche and Bollinger (22). This amount of $\mathrm{Pb}$ was chosen to match the concentration measured in natural samples.

Micro-Raman spectroscopy was performed using a Dilor XY 800 Raman spectrometer giving a sample footprint of 1 micron (microscope with a $\times 100$ objective) (ISTO facilities, Orléans, France). The excitation source is an $\mathrm{Ar}^{+}$laser (Coherent Radiation) operating at $514.5 \mathrm{~nm}$. The incident power was limited to $2-5 \mathrm{~mW}$ to avoid local heating of the sample that may cause mineral transformation as reported in previous studies (23-25). Typical spectral resolution for the Raman system with an $18001 / \mathrm{mm}$ grating monochromator was less than $1 \mathrm{~cm}^{-1}$ with a spatial resolution of $1 \mu \mathrm{m}^{3}$. 
The spectra were collected at room temperature from 60 to $1579 \mathrm{~cm}^{-1}$ with a $15 \mathrm{~min}$ integration time.

Secondary (SE) and backscattered (BSE) images were obtained with a Philips XL-30 scanning electron microscope (SEM) coupled to an energy dispersive X-ray analyzer system (EDAX) for morphological and semiquantitative chemical information (SERMIEL, Limoges, France). Electron probe microanalysis (EPMA) was used to investigate in situ the major elements (CAMECA SX-50 equipped with an EDAX system and 4 wavelength dispersive spectrometers operating at $15 \mathrm{kV}$ and $4 \mathrm{nA}$ beam current) (CAMPARIS, Paris, France). Standard reference materials (natural and synthetic silicates, oxides, and sulfide minerals) were used to calibrate the microprobe.

Chemical analyses were performed for heavy elements $(Z$ $\geq 25$ ) by nuclear microprobe particle-induced X-ray emission technique (micro-PIXE). These measurements were carried out at the CEA/CNRS, Laboratoire Pierre Süe (LPS) nuclear microprobe facility in Saclay (France) using $3 \mathrm{MeV} \mathrm{H}^{+}$. PIXE spectra were collected using a $\mathrm{Si}(\mathrm{Li}) \mathrm{X}$-ray detector. A 123 $\mu \mathrm{m}$-thick Mylar filter was positioned in front of this detector to stop backscattered protons. A $250 \mu$ m-thick Al-filter was added to the Mylar filter to attenuate the Fe K $\alpha$ X-rays. The intensity of the proton beam, used to acquire elemental distribution maps, was fixed at $200 \mathrm{pA}$ and was focused to approximately $2 \times 2 \mu \mathrm{m}$. Samples were scanned under the beam on selected areas. Pyrite and $\mathrm{Cu}$ metal were used as calibration standards for the PIXE analyses.

Microfocused scanning X-ray fluorescence (SXRF), microX-ray absorption spectroscopy (XAS), and microscanning $\mathrm{X}$-ray diffraction (SXRD) measurements were carried out at beamlines 10.3.2 and 7.3.3 of the Advanced Light Source, Lawrence Berkeley National Laboratory, Berkeley, USA $(26,27)$.

For the micro-SXRF and micro-XAS experiments at beamline 10.3.2, samples were attached to an $X Y Z$ stage oriented $45^{\circ}$ to the beam. Micro-SXRF elemental maps were obtained by scanning a thin section under a monochromatic beam with incident energies at 12985 and $13085 \mathrm{eV}$ and with a beam spot size on the sample of $5 \mu \mathrm{m}(\mathrm{H}) \times 5 \mu \mathrm{m}(\mathrm{V})$ full width at half-maximum (FWHM). These maps were done at two energies because the $\mathrm{Pb}$ and As fluorescence energies are the same to within the detector resolution, so in order to separate $\mathrm{Pb}$ from $\mathrm{As}$, one map was done above the $\mathrm{Pb}$ $\mathrm{L}_{3}$-edge and one below, and the $\mathrm{Pb}$ signal was derived by subtraction. The step size was $5 \times 5 \mu \mathrm{m}$, and the dwell time per point was $50 \mathrm{~ms}$. Micro-SXRF maps and micro-XAS spectra were collected in fluorescence-yield mode using a seven element $\mathrm{Ge}$ detector. $\mathrm{Pb} \mathrm{L}_{3}$-edge EXAFS spectra were recorded on several spots localized within one $7 \mu \mathrm{m} \times 7 \mu \mathrm{m}$ area. The energy calibration for the XANES experiments at the $\mathrm{Pb} \mathrm{L}_{3}$ edge was set to $13035 \mathrm{eV}$ for $\mathrm{Pb}$ metal. Five XANES scans were acquired on each spot and were averaged. The XAS spectra were then background subtracted and normalized post-edge using standard procedures. XAS data analysis was performed using the 10.3.2 LabView software suite (http://xraysweb.lbl.gov/uxas/Beamline/Software/Software.htm) and the IFEFFIT suite software.

Microfocused SXRD maps were recorded at beamline 7.3.3 (now 12.3.2) (27) using an incident X-ray beam at $6 \mathrm{keV}$ and a $1024 \times 1024$ pixels MAR CCD detector with an exposure time of $300 \mathrm{~s}$ per frame and a total scan acquisition time of $18 \mathrm{~h}$ for an area of $126 \mu \mathrm{m} \times 88 \mu \mathrm{m}$. XRD patterns were recorded in reflection geometry with the thin section samples fixed to an $X Y Z$ stage oriented at $10^{\circ}$ to the incident $\mathrm{X}$-ray beam. The incident photon beam was $1 \mu \mathrm{m} \times 1 \mu \mathrm{m}$, with a lateral beam size on the sample oriented at $10^{\circ}$ of $300 \mu \mathrm{m}$ (H) x $400 \mu \mathrm{m}(\mathrm{V})$. Monochromatic XRD data were processed using the microdiffraction analysis software XMAS available at the beamline. Unit cell dimensions have been estimated on the collected reflections by the X-Pert HighScore Plus program.

\section{Results and Discussion}

Figure 1 shows an example of an elemental map obtained by SEM-EDAX on two grains of Pb-bearing phases. Barium, $\mathrm{Fe}, \mathrm{Pb}$, and $\mathrm{S}$ appear to be similarly distributed in the small grains located in the pores of the sample. Moreover, Fe is more widely distributed and contributes to other phases. However, because of the overlapping of the spectral windows between $\mathrm{PbM} \alpha$ and $\mathrm{SK} \alpha$, it is difficult to distinguish $\mathrm{Pb}$ from $\mathrm{S}$. EPMA shows that $\mathrm{Pb}$ concentrations are quite homogeneous over the $\mathrm{Fe}$ and $\mathrm{Ba}$-rich compounds containing up to $3.7 \mathrm{wt} \%$ of $\mathrm{PbO}$ (Figure 1) and that these compounds are assumed to be hydrated or hydroxylated as the analyses sum up to 88 wt \%.

Because of its higher sensitivity compared to EPMA, PIXE is used to determine trace element content $(28,29)$ and affords higher precision in determining elemental distribution. The microfocused PIXE map of $\mathrm{Ba}, \mathrm{Fe}$, and $\mathrm{Pb}$ in the sample highlights the distribution of $\mathrm{Pb}$, which closely matches that of Ba (Figure 2a). Despite the fact that SEM, EPMA, and PIXE enable us to determine the distribution of $\mathrm{Ba}, \mathrm{Fe}$, and $\mathrm{Pb}$ as well as to quantify their contribution to the studied phases, these techniques were not sufficient in this case to mineralogically identify the $\mathrm{Pb}$-host phase.

A typical micro-Raman spectrum obtained on that metalbearing phase is presented in Figure $2 \mathrm{~b}$. The bands at 241, $296,391,548,683,1130$, and $1298 \mathrm{~cm}^{-1}$ have been ascribed to goethite $(23,30,31)$. Those at $456\left(v_{2}\right), 617\left(v_{4}\right), 631\left(v_{4}\right)$, $986\left(v_{1}\right)$, and $1130\left(v_{3}\right) \mathrm{cm}^{-1}$ have been ascribed to barite, with other weak bands at 1071 and $1093 \mathrm{~cm}^{-1}$ attributed to $v_{3}$ vibrational modes (32-34). The sharp $v_{1}$ band shows a shoulder at $973 \mathrm{~cm}^{-1}$, and a very weak band has also been noted at $1048 \mathrm{~cm}^{-1}$, close to bands obtained for $\mathrm{PbO} \cdot \mathrm{PbSO}_{4}$ phases at 976 and $1055 \mathrm{~cm}^{-1}$ (33). The Pb-rich phase is thus identified as a mixture of barite and goethite at the resolution of the Raman (here, $1 \mu \mathrm{m}^{3}$ ).

Micro-SXRD was performed to complement the microRaman results and to determine whether or not $\mathrm{Pb}$ is equally distributed in goethite and barite or if $\mathrm{Pb}$ is bonded preferentially with one or the other. Figure 3 shows microSXRD mineralogical maps, evidencing the discrimination of barite from the goethite. The distribution maps of barite and goethite are presented at their most intense peaks at 3.44 and $4.18 \AA$, respectively. These mineralogical maps indicate that the grains are mainly composed of barite and that goethite constitutes the other phases distributed around the pores. Thus, the micro-SXRD mineral species maps show that barite is the main component of the grains containing $\mathrm{Pb}$.

Therefore, Raman investigations and synchrotron-based studies both suggest that, in the analyzed $\mathrm{Pb}$-rich phase, $\mathrm{Pb}$ is incorporated into barite by $\mathrm{Ba} / \mathrm{Pb}$ substitution instead of into goethite. Lead associated with barite in mineralized veins has been extensively reported in various deposits such as for the Mississippi Valley-type ore deposit found within carbonate rocks (35). This association may be attributed to coprecipitation of $\mathrm{Pb}$-rich sulfides (galena) with the gangue minerals such as sulfates (barite, anhydrite) $(36,37)$. In our case, no evidence of galena has been reported. The major sulfides detected were pyrite, sphalerite, and chalcopyrite, and none of them contain Pb-rich inclusions (21). However, $\mathrm{Pb}$, in the hundreds of ppm range, has been reported in barite from volcanic-hosted massive sulfide deposits (38) and can also be linked to barite as an anglesobarite called hokutolite (39-41). Anglesite $\left(\mathrm{PbSO}_{4}\right)$ is isostructural with barite and has similar cell parameters $(32,42)$. Thus, possible 


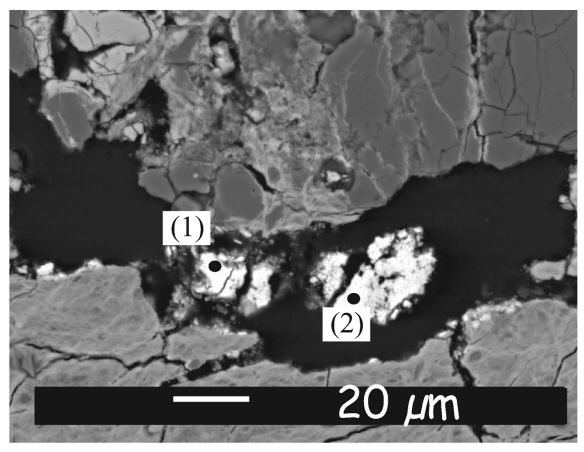

(1)

$\mathrm{PbO}=2.9 \quad \mathrm{PbO}=3.7$

$\mathrm{BaO}=24.9 \quad \mathrm{BaO}=26.6$

$\mathrm{SO}_{3}=18.7 \quad \mathrm{SO}_{3}=19.2$

$\mathrm{FeO}=38.7 \quad \mathrm{FeO}=36.4$

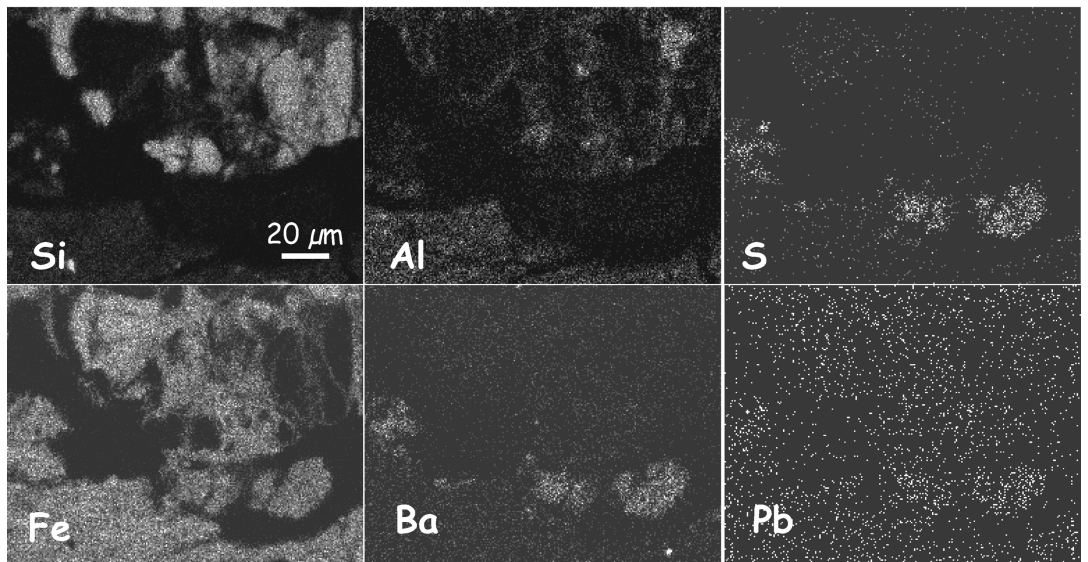

FIGURE 1. Scanning electron microscope image in BSE of the $\mathrm{Pb}$-rich $\mathrm{Fe}-\mathrm{Ba}$ compounds and examples of EPMA analyses (spots 1 and 2) in wt \% obtained on the two bright grains located in the pores. The average composition of these compounds obtained by EPMA is $\mathrm{FeO}=39.73$ wt $\%, \mathrm{BaO}=24.84 \mathrm{wt} \%, \mathrm{SO}_{3}=18.05 \mathrm{wt} \%$, and $\mathrm{PbO}=2.65 \mathrm{wt} \%$. The X-ray elemental map of the zone is shown at the $\mathrm{K} \alpha$ energy peak for $\mathrm{Si}, \mathrm{Al}, \mathrm{S}, \mathrm{Fe}$, and $\mathrm{Ba}$ and at the $\mathrm{L} \alpha$ energy peak for $\mathrm{Pb}$ to avoid overlapping between $\mathrm{Pb}$ and $\mathrm{S}$ (acquisition for 200 scans; $t=45 \mathrm{~min}$ ).

(a)

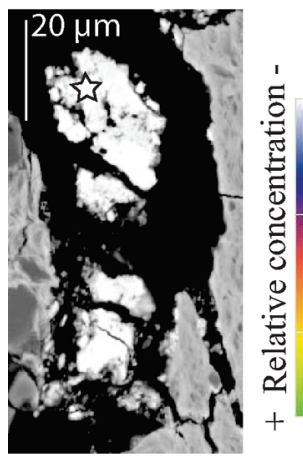

(b)

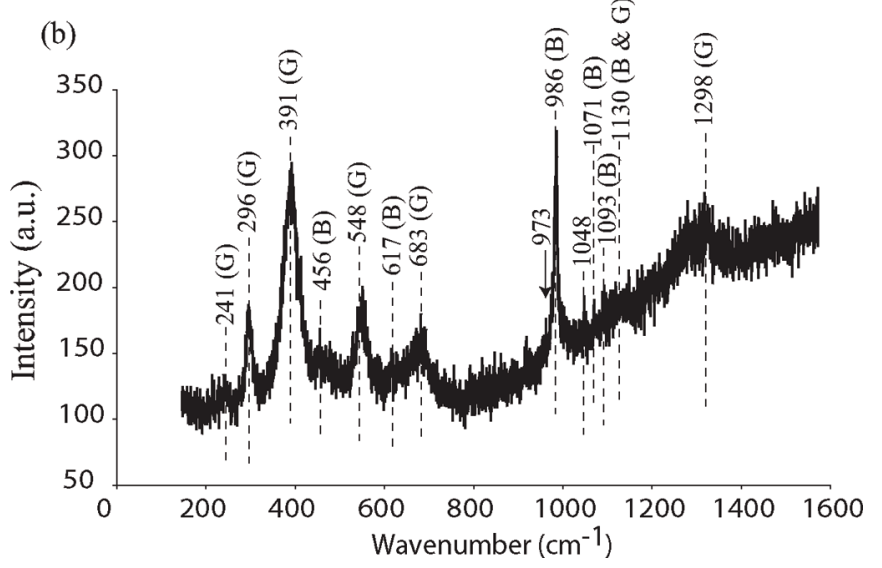

FIGURE 2. (a) Micro-PIXE elemental map of $\mathrm{Pb}, \mathrm{Ba}$, and $\mathrm{Fe}$ indicating their relative concentration in the sample with $\mathrm{Ba}$ and $\mathrm{Fe}$ as the main elements. The white star on the BSE image shows one example of the location of the Raman acquisitions; (b) Micro-Raman spectrum obtained on the most $\mathrm{Pb}$-rich part of the grains, showing characteristic bands of goethite (G) and barite (B).

substitution of $\mathrm{Ba}$ by $\mathrm{Pb}, \mathrm{Ba}_{(1-x)} \mathrm{Pb}_{x} \mathrm{SO}_{4}$, if not common, has been reported, forming a complete solid-solution series between barite and anglesite $(41,42)$. From the Ba-rich end toward the Pb-rich end of the solid-solution series, the cell parameters vary continuously and systematically (40). In this study, the incorporation of $\mathrm{Pb}$ within barite is evidenced by the characteristic bands at $1047 \mathrm{~cm}^{-1}\left(\mathrm{PbO} \cdot \mathrm{PbSO}_{4}\right)(33)$ and by the shift of several bands reported in the Raman spectrum, for instance at 1071 and $1093 \mathrm{~cm}^{-1}$ as compared to those observed for pure barite at 1075 and $1110 \mathrm{~cm}^{-1}$, which are attributed to the $v_{3}$ vibrational modes of $\mathrm{PbSO}_{4}$ (32). Furthermore, the peak of the symmetric stretching mode $\left(v_{1}\right)$ measured at $986 \mathrm{~cm}^{-1}$ in our sample was already reported for pure barite in previous studies (e.g., ref 34) or with frequency values slightly higher at $987(32,43), 988$ (33), or at $990 \mathrm{~cm}^{-1}(41)$. The $v_{1}$ band corresponds to the stretching of the $\mathrm{S}-\mathrm{O}$ bond in the $\mathrm{SO}_{4}{ }^{2-}$ group $\left(\nu \mathrm{SO}_{4}{ }^{2-}\right)$ and is the most characteristic for determining the composition of the solidsolution between anglesite and barite. Thus, in our case, the $v_{1}$ band may also indicate the presence of $\mathrm{Pb}$ according to the $v_{1}$ band reported in previous work $(33,41)$ and because of the shoulder at $973 \mathrm{~cm}^{-1}$. Moreover, Lee et al. (41) show that the Raman shift of the $v_{1}$ band is a function of the $\mathrm{BaSO}_{4}$ content in the $(\mathrm{Ba}, \mathrm{Pb}) \mathrm{SO}_{4}$ solid solution, ranging from 978.5 $\mathrm{cm}^{-1}$ for anglesite (44) to $986-990 \mathrm{~cm}^{-1}$ for barite (32-34, $41,43)$. The $v_{1}$ band on our Raman spectrum was observed at $986 \mathrm{~cm}^{-1}$, which should correspond roughly to $70-90 \%$ of $\mathrm{BaSO}_{4}$ content (mol \%) according to previous work (41), and strongly influences the cell parameters. The cell parameters of the studied $\mathrm{Pb}$-rich barite have been determined by $\mu \mathrm{SXRD}$ 

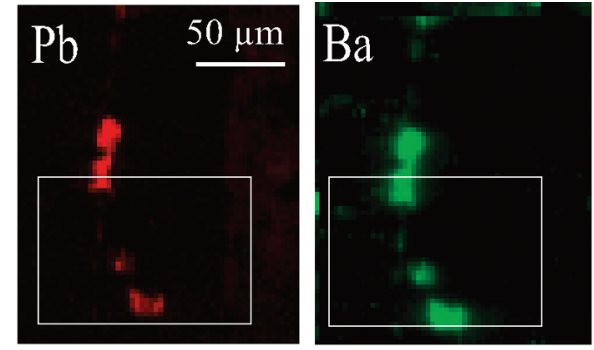

Barite $(3.44 \AA)$
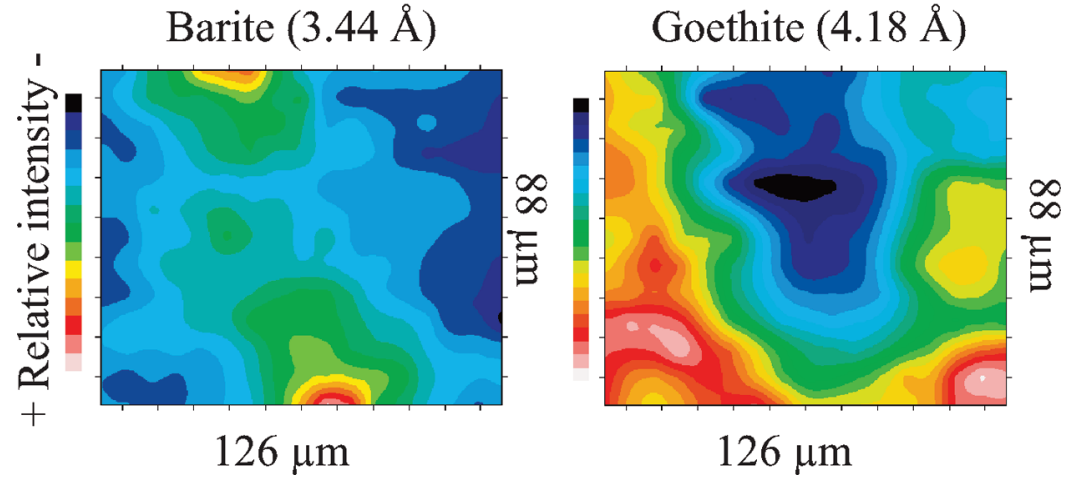

FIGURE 3. Micro-SXRF elemental maps for $\mathrm{Ba}, \mathrm{Pb}$, and Fe. The white square shows the area analyzed by micro-SXRD (dimension 126 $\times 88 \mu \mathrm{m}$, acquisition time: $18 \mathrm{~h}$ ). Mineral species maps obtained at 3.44 and $4.18 \AA$ by micro-SXRD show the distribution of barite and goethite, respectively.
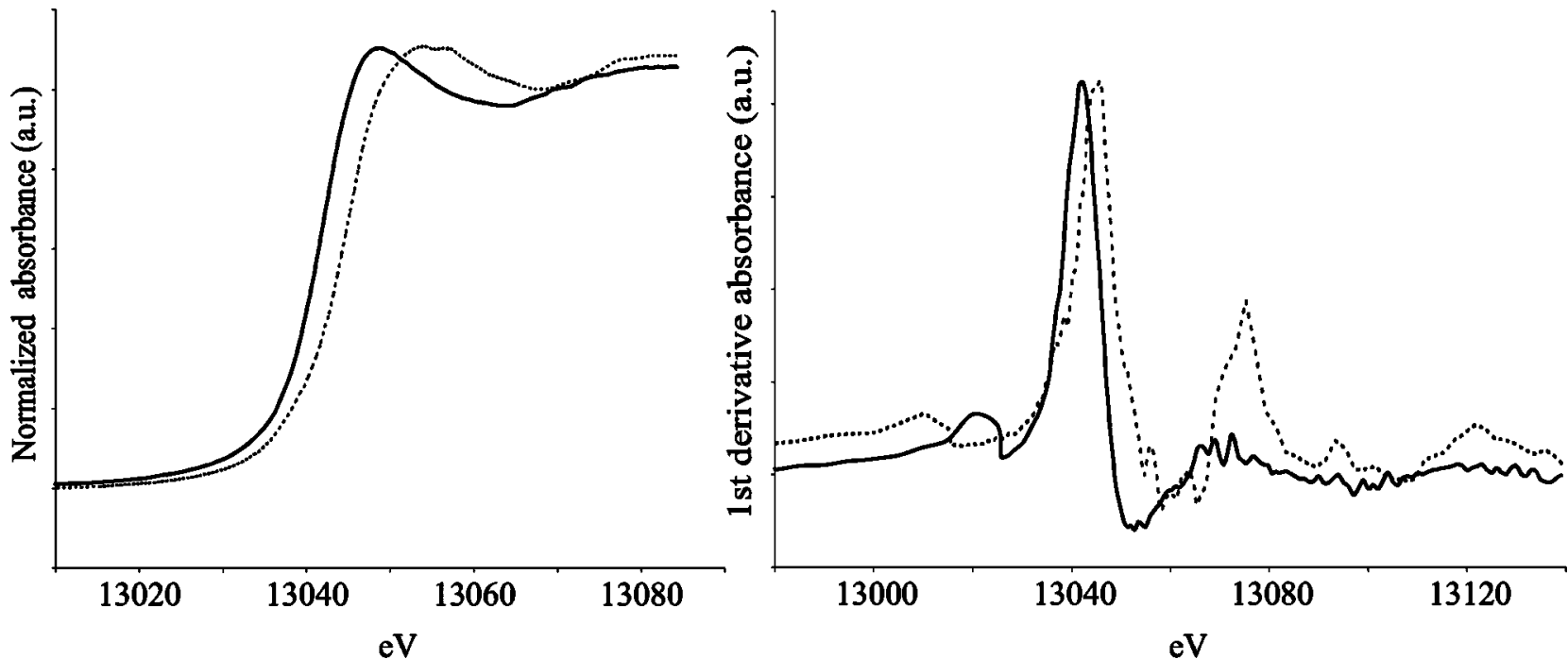

FIGURE 4. Normalized XANES spectra of model compound ( $\mathrm{Pb}$-adsorbed barite, dashed line) and $\mathrm{Pb}$-rich natural sample (solid line). The corresponding first derivative spectra are presented to emphasize their fine structures.

analyses and closely match with those reported by Sasaki et al. (45): $a=8.795 \AA, b=5.451 \AA$, and $c=7.117 \AA$, whereas the cell parameters of pure $\mathrm{BaSO}_{4}$ are: $a=8.896 \AA, b=5.462$ $\AA$, and $c=7.171 \AA$ (41). These results are in agreement with the $\mathrm{Pb}$ contribution estimated by Raman.

To determine the speciation of $\mathrm{Pb}$ (oxidation state and mineralogy), $\mathrm{Pb} \mathrm{L}_{3}$ micro-XANES were performed. Microfocused XANES spectra of the sample and the Pb-sorbed barite model compound are compared in Figure 4. Normalized and first derivative spectra are shown, the latter emphasizing the details of the normalized spectra. The normalized spectrum of the model compound shows a broader band than the natural sample. Both sample derivative spectra exhibit a peak at $13042-13045 \mathrm{eV}$, corresponding to the $2 \mathrm{p} \rightarrow 6 \mathrm{~d}$ transition indicative of the $\mathrm{Pb}^{2+}$ form (46). MicroXANES data show that $\mathrm{Pb}$ is present as $\mathrm{Pb}^{2+}$, which is in agreement with the in situ geochemical conditions $(3<\mathrm{pH}$ $<4$ and $\mathrm{Eh} \sim 500 \mathrm{mV}$ ). The incorporation of $\mathrm{Pb}$ within barite should be stable under these conditions; furthermore, barite shows very low solubility under atmospheric conditions and increases with increasing temperature (38). However, this solubility is highly dependent on the presence of other elements such as metals, which may combine with barite. Barite is the only $\mathrm{Pb}$-bearing phase identified in the iron hardpan of the mining site and constitutes a very small fraction $(\sim 1 \%)$ of the determined mineralogy; however, the watershed includes a part of the sulfide ore body that was not mined, in which other Pb-bearing phases may have precipitated. Thus, studying the stability of barite to forecast the potential release of $\mathrm{Pb}$ is necessary because of the $\mathrm{Pb}$ amounts trapped by this mineral and because the watershed is located in a heavily urbanized area. It is, however, not sufficient, and further studies of the nonaffected sulfide ore body are required.

The combination of in situ micro-Raman, SXRD and XANES analyses show the mineralogical distribution of the highly toxic element $\mathrm{Pb}$ and permit identification of its association with $\mathrm{Ba}$. This approach allowed us to 
discriminate which of the minerals between barite and goethite could trap this element in the studied hardpan. Here, $\mathrm{Pb}$ is incorporated into barite, forming an anglesitebarite solid-solution. Raman bands allow qualitative identification and give an estimate of the $\mathrm{Pb} / \mathrm{Ba}$ ratio. The waste rock pile where the samples were collected is directly affected by runoff. However, according to the high stability of barite in atmospheric conditions, the incorporation of $\mathrm{Pb}$ in this mineral acts as a natural efficient sink for $\mathrm{Pb}$.

\section{Acknowledgments}

Financial support from the national program GDR Transmet (INSU program) is acknowledged. We thank Michel Peymirat for the samples preparation, Maxime Vanaecker for his assistance during the ALS experiments and J. M. Bény for his help on the micro-Raman. The operations of the ALS at LBNL are supported by the Director, Office of Science, Office of Basic Energy Sciences, US Department of Energy under contract No. DE-AC02-05CH11231. We thank three anonymous reviewers for their useful comments on the manuscript.

\section{Literature Cited}

(1) Foster, A. L.; Brown, G. E., Jr.; Tingle, T. N.; Parks, G. A. Quantitative arsenic speciation in mine tailings using X-ray absorption spectroscopy. Am. Mineral. 1998, 83, 553-568.

(2) Manceau, A.; Tamura, N.; Marcus, M. A.; Macdowell, A. A.; Celestre, R. S.; Sublett, R. E.; Sposito, G.; Padmore, H. A. Deciphering Ni sequestration in soil ferromanganese nodules by combining X-ray fluorescence, absorption, and diffraction at micrometer scales of resolution. Am. Mineral. 2002, 87, 14941499.

(3) Kirpichtchikova, T. A.; Manceau, A.; Spadini, L.; Panfili, F.; Marcus, M. A.; Jacquet, T. Speciation and solubility of heavy metals in contaminated soil using X-ray microfluorescence, EXAFS spectroscopy, chemical extraction, and thermodynamic modelling. Geochim. Cosmochim. Acta 2006, 70, 2163-2190.

(4) Williams, A. B.; Scheckel, K. G.; Tolaymat, T.; Impellitteri, C. A. Mineralogy and characterization of arsenic, iron, and lead in a mine waste-derived fertilizer. Environ. Sci. Technol. 2006, 40, 4874-4879.

(5) Carbone, C.; Di Benedetto, F.; Marescotti, P.; Martinelli, A.; Sangregorio, C.; Cipriani, C.; Lucchetti, G.; Romanelli, M. Genetic evolution of nanocrystalline $\mathrm{Fe}$ oxide and oxyhydroxide assemblages from the Libiola mine (eastern Liguria, Italy): Structural and microstructural investigations. Eur. J. Mineral. 2005, 17, 785-795.

(6) Montero, I. C.; Brimhall, G. H.; Alpers, C. N.; Swayze, G. A. Characterization of waste rock associated with acid drainage at the Penn Mine, California, by ground-based visible to shortwave infrared reflectance spectroscopy assisted by digital mapping. Chem. Geol. 2005, 215, 453-472.

(7) Walker, S. R.; Jamieson, H. E.; Lanzirotti, A.; Andrade, C. F.; Hall, G. E. M. The speciation of arsenic in iron oxides in mine wastes from the Giant gold mine, N.W.T.: application of synchrotron micro-XRD and micro-XANES at the grain scale. Can. Mineral. 2005, 43, 1205-1224.

(8) Kalbasi, M.; Peryea, F. J.; Lindsay, W. L.; Drake, S. R. Measurement of divalent lead activity in lead arsenate contaminated soils. Soil Sci. Soc. Am. J. 1995, 59, 1274-1280.

(9) Veeresh, H.; Tripathy, S.; Chaudhuri, D.; Hart, B. R.; Powell, M. A. Sorption and distribution of adsorbed metals in three soils of India. Appl. Geochem. 2003, 18, 1723-1731.

(10) Committee on Superfund Site Assessment and Remediation in the Coeur d'Alene River Basin, National Research Council. Superfund and Mining Megasites: Lessons from the Coeur d'Alene River Basin; The National Academies Press: Washington DC, 2005.

(11) Davis, A.; Drexler, J. W.; Ruby, M. V.; Nicholson, A. Micromineralogy of mine wastes in relation to lead bioavailability, Butte, Montana. Environ. Sci. Technol. 1993, 27, 1415-1425.

(12) Hudson-Edwards, K. A.; Macklin, M. G.; Curtis, C. D.; Vaughan, D. J. Processes of formation and distribution of $\mathrm{Pb}-, \mathrm{Zn}-, \mathrm{Cd}-$, and $\mathrm{Cu}$-bearing minerals in the Tyne basin, north-eastern England: implications for metal-contaminated river systems. Environ. Sci. Technol. 1996, 30, 72-80.
(13) Morin, G.; Ostergren, J. D.; Juillot, F.; Ildefonse, P.; Calas, G.; Brown, G. E., Jr. XAFS determination of the chemical form of lead in smelter-contaminated soils and mine tailings: importance of adsorption processes. Am. Mineral. 1999, 84, 420-434.

(14) Jeong, G. Y.; Lee, B. Y. Secondary mineralogy and microtextures of weathered sulfides and manganoan carbonates in mine wasterock dumps, with implications for heavy-metal fixation. Am. Mineral. 2003, 88, 1933-1942.

(15) Ramos Arroyo, Y. R.; Siebe, C. Weathering of sulphide minerals and trace element speciation in tailings of various ages in the Guanajuato mining district, Mexico. Catena. 2007, 71, 497-506.

(16) McKenzie, R. M. The adsorption of lead and other heavy metals on oxides of manganese and iron. Aust. J. Soil Sci. 1980, 18, 61-73.

(17) Turner, R. Mechanism for the formation of the mineralized Mn deposits at Merehead Quarry, Cranmore, Somerset, England. Mineral. Mag. 2006, 70, 629-653.

(18) Castendyk, D. N.; Webster-Brown, J. G. Sensitivity analyses in pit lake prediction, Martha mine, New Zealand 2: Geochemistry, water-rock reactions, and surface adsorption. Chem. Geol. 2007, 244, 56-73.

(19) Haury, J. F., Jr. Measurement and manipulation of copper speciation and toxicity in urban runoff, acid mine drainage, and contaminated discharge groundwater. Ph.D. thesis, University of California, Berkeley, 2001.

(20) Graymer, R. W. Digital geologic map and map database of the Oakland metropolitan area, Alameda, Contra Costa, and San Francisco Counties, California. Miscellaneous Field Studies Report 2342; U.S. Geological Survey: Reston, Virginia, 2000.

(21) Clark, C. W. Geology and ore deposits of Leona rhyolite. Bull. Dept. Geology 1917, 10, 361-382.; University of California Publications.

(22) Davranche, M.; Bollinger, J.-C. Release of metals from iron oxyhydroxides under reductive conditions: effect of metal/solid interactions. J. Colloid Interface Sci. 2000, 232, 165-173.

(23) De Faria, D. L. A.; Venâncio Silva, S.; De Oliveira, M. T. Raman microspectroscopy of some iron oxides and oxyhydroxides. $J$. Raman Spectrosc. 1997, 28, 873-878.

(24) Mazzetti, L.; Thistlethwaite, P. J. Raman spectra and thermal transformations of ferrihydrite and schwertmannite. J. Raman Spectrosc. 2002, 33, 104-111.

(25) Pérez-León, C.; Kador, L.; Zhang, M.; Müller, A. H. In situ laserinduced formation of $\alpha-\mathrm{Fe}_{2} \mathrm{O}_{3}$ from $\mathrm{Fe}^{3+}$ ions in a cylindrical core-shell polymer brush. J. Raman Spectrosc. 2004, 35, 165169.

(26) Marcus, M. A.; Macdowell, A. A.; Celestre, R. S.; Manceau, A.; Miller, T.; Padmore, H. A.; Sublett, R. E. Beamline 10.3.2 at ALS: a hard X-ray microprobe for environmental and materials sciences. J. Synchrotron. Rad. 2004, 11, 239-247.

(27) Tamura, N.; Spolenak, R.; Valek, B. C.; Manceau, A.; Meier Chang, M.; Celestre, R. S.; Macdowell, A. A.; Padmore, H. A.; Patel, J. R. Submicron $\mathrm{x}$-ray diffraction and its applications to problems in materials and environmental science. Rev. Sci. Instrum. 2002, 73, 1369-1372.

(28) Campbell, J. L.; Teesdale, W. J.; Halden, N. M. Theory, practice and application of micro-PIXE analysis and element-distribution maps. Can. Min. 1995, 33, 279-292.

(29) Halden, N. M.; Campbell, J. L.; Teesdale, W. J. PIXE analysis in mineralogy and geochemistry. Can. Min. 1995, 33, 293-302.

(30) Dünnwald, J.; Otto, A. An investigation of phase transitions in rust layers using Raman spectroscopy. Corros. Sci. 1989, 29, 1167-1176.

(31) Courtin-Nomade, A.; Bril, H.; Neel, C.; Lenain, J.-F. Arsenic in iron cements developed within tailings of a former metalliferous mine-Enguialès, Aveyron, France. Appl. Geochem. 2003, 18, 395-408.

(32) Miyake, M.; Minato, I.; Morikawa, H.; Iwai, S.-I. Crystal structures and sulphate force constants of barite, celestite, and anglesite. Am. Mineral. 1978, 63, 506-510.

(33) Correia, A. M.; Clark, R. J. H.; Ribeiro, M. I. M.; Duarte, M. L. T. S. Pigment study by Raman microscopy of 23 paintings by the Portuguese artist Henrique Pousão (1859-1884). J. Raman Spectrosc. 2007, 38, 1390-1405.

(34) Edwards, H. G. M.; Beale, E.; Garrington, N. C.; Alia, J.-M. FTRaman spectroscopy of pigments on a Hindu statue, Kali Walking on Siva. J. Raman Spectrosc. 2007, 38, 316-322.

(35) Bouch, J. E.; Naden, J.; Shepherd, T. J.; McKervey, J. A.; Young, B.; Benham, A. J.; Sloane, H. J. Direct evidence of fluid mixing in the formation of stratabound $\mathrm{Pb}-\mathrm{Zn}-\mathrm{Ba}-\mathrm{F}$ mineralisation in the Alston Block, North Pennine Orefield (England). Mineral. Deposita 2006, 41, 821-835. 
(36) Sverjensky, D. A. The diverse origins of Mississippi Valley-type Zn-Pb-Ba-F deposits. Chron. Rech. Min. 1989, 495, 5-13.

(37) Stoffel, B.; Wilkinson, J. J.; Jeffries, T. E. Metal transport and deposition in hydrothermal veins revealed by $213 \mathrm{~nm}$ UV laser ablation microanalysis of single fluid inclusions. Am. J. Sci. 2004, 304, 533-557.

(38) Hanor, J. S. Barite-Celestine geochemistry and environments of formation. In Sulfate Minerals: Crystallography, Geochemistry, and Environmental Significance. Reviews in Mineralogy and Geochemistry; Alpers, C. N., Jambor, J. L., Nordstrom, D. K., Eds.; Mineralogical Society of America: Washington DC, 2000; Vol. 40, pp 305-350.

(39) Su, H.-Y.; Yu, S.-C. Dopant effect on Hokutolite crystals synthesized with hydrothermal process. West. Pacific Earth Sci. 2002, 2, 301-318.

(40) Wang, H.-R.; Lee, J.-S.; Yu, S.-C. Synthesis of zoning-free $\mathrm{BaSO}_{4}$ $\mathrm{PbSO}_{4}$ solid solution and its structural characterizations. $Z$. Kristallogr. 2002, 217, 143-148.

(41) Lee, J.-S.; Wang, H.-R.; Iizuka, Y.; Yu, S.-C. Crystal structure and Raman spectral studies of $\mathrm{BasSO}_{4}-\mathrm{PbSO}_{4}$ solid solution. $Z$. Kristallogr. 2005, 220, 1-9.
(42) Jacobsen, S. D.; Smyth, J. R.; Swope, R. J. Rigid-body character of the $\mathrm{SO}_{4}$ groups in celestine, anglesite and barite. Can. Min. 1998, 36, 1053-1060.

(43) Touray, J.-C.; Bény, C.; Bouhlel, S. Electron microprobe and Raman microspectrometry characterization of barite-celestite solid solutions. C. R. Acad. Sci., Ser. IIa: Sci. Terre Planets 1988, 306, 1353-1357.

(44) Aze, S.; Vallet, J.-M.; Baronnet, A.; Grauby, O. The fading of red lead pigment in wall paintings: Tracking the physico-chemical transformations by means of complementary micro-analysis techniques. Eur. J. Mineral. 2006, 18, 835-843.

(45) Sasaki, N.; Kayahara, Y.; Watanuki, K. Chemical composition and growth conditions of hokutolite crystallized by the splashing of hot spring waters at Tamagawa hot spring. J. Miner. Soc. Jpn. 1992, 21, 113-121.

(46) Takahashi, Y.; Manceau, A.; Geoffroy, N.; Marcus, M. A.; Usui, A. Chemical and structural control of the partitioning of $\mathrm{Co}, \mathrm{Ce}$, and $\mathrm{Pb}$ in marine ferromanganese oxides. Geochim. Cosmochim. Acta 2007, 71, 984-1008.

ES702822K 